\title{
Public Versus Private: Does It Matter for Water Conservation? Insights from California
}

\author{
Giorgos Kallis · Isha Ray • Julian Fulton • \\ James E. McMahon
}

Received: 30 March 2009/Accepted: 9 November 2009/Published online: 5 December 2009

(c) The Author(s) 2009. This article is published with open access at Springerlink.com

\begin{abstract}
This article asks three connected questions: First, does the public view private and public utilities differently, and if so, does this affect attitudes to conservation? Second, do public and private utilities differ in their approaches to conservation? Finally, do differences in the approaches of the utilities, if any, relate to differences in public attitudes? We survey public attitudes in California toward (hypothetical but plausible) voluntary and mandated water conservation, as well as to price increases, during a recent period of shortage. We do this by interviewing households in three pairs of adjacent public and private utilities. We also survey managers of public and private urban water utilities to see if they differ in their approaches to conservation and to their customers. On the user side we do not find pronounced differences, though a minority of customers in all private companies would be more willing to conserve or pay higher prices under a
\end{abstract}

Giorgos Kallis, ICREA Researcher.

G. Kallis $(\bowtie)$

ICTA (Institut de Ciència i Tecnologia Ambientals), Universidad Autonoma de Barcelona, ETSE, QC/3095, 08193 Bellatera,

Barcelona, Spain

e-mail: giorgoskallis@gmail.com

I. Ray $\cdot$ J. Fulton

Energy \& Resources Group, University of California at

Berkeley, 310 Barrows Hall \#3050, Berkeley, CA 94720, USA

e-mail: isharay@berkeley.edu

J. Fulton

e-mail: julianfulton@berkeley.edu

\section{J. E. McMahon}

Environmental Energy Technologies Division, Energy Analysis

Department, Lawrence Berkeley National Laboratory,

1 Cyclotron Road, 90R4000, Berkeley, CA 94720-8136, USA

e-mail: JEMcMahon@LBL.gov public operator. No respondent in public utility said the reverse. Negative attitudes toward private operators were most pronounced in the pair marked by a controversial recent privatization and a price hike. Nonetheless, we find that California's history of recurrent droughts and the visible role of the state in water supply and drought management undermine the distinction between public and private. Private utilities themselves work to underplay the distinction by stressing the collective ownership of the water source and the collective value of conservation. Overall, California's public utilities appear more proactive and target-oriented in asking their customers to conserve than their private counterparts and the state continues to be important in legitimating and guiding conservation behavior, whether the utility is in public hands or private.

Keywords Water conservation - Droughts . Privatization $\cdot$ Public perceptions $\cdot$ California

\section{Introduction}

Climate change is expected to increase the frequency and intensity of droughts in many parts of the world (Kallis 2008). Conservation in the face of supply constraints is a key adaptation option for the urban water sector (Ivey and others 2005). This might include longer-term policies such as consumer education, retrofitting and price reform, as well as short-term responses, such as voluntary appeals for restraints in water consumption, mandatory cutbacks of certain uses or tariffs penalizing excessive consumption (Baumann and others 1998; Butler and Memon 2006). There is a growing literature on the effectiveness of different tools to manage domestic water demand (Martínez-Espiñeira 2002; Mazzanti and Montini 2006; Nauges and Thomas 2003; Wentz and 
Gober 2007; Butler and Memon 2006; Dalhuisen and others 2003; Domene and Saurí 2006).

In these works, the determinants of conservation behavior are typically the management tools themselves, and the socio-economic characteristics of the water users, such as income or types of uses. Conservation behavior is implicitly assumed to be independent of the institutional set-up, the relationship between the user and the provider, or whether the control of the system is public or private. Willingness to pay is implicitly assumed to be independent of who is to be paid. Yet anecdotal evidence from cities in the UK, where formerly public water utilities have been fully privatized, suggests that users might become less receptive to conservation appeals or mandatory cutbacks (Haughton 1998; Howarth 1999; Bakker 2000, 2005; Howarth and Butler 2004). Greater resistance to price changes has also been noted elsewhere (Hall and Lobina 2004). That institutional set-up might affect conservation behavior or willingness to pay is not totally surprising; for example, ecological economic studies critical of mainstream valuation studies have long argued that willingness to pay for conservation depends on institutional structure and the specifics of who is to be paid (Jacobs 1994; Vatn 2005; Spash 2008). Anecdotal evidence also suggests that privatization changes the utilities' approach toward conservation, private utilities generally being more reluctant to impose hardships on their users or to mandate cut-backs (Howarth 1999).

User cooperation and compliance with water use restrictions are widely-used and cost-effective tools for dealing with temporary shortages or multi-year droughts. If private utilities face resistance in employing such tools, their response options to crises are reduced. This is all the more true if the main alternative, higher water prices or special tariffs, are also likely to be strongly resisted (see Dinar 2000). The impacts of private sector participation in water services have attracted considerable interest (e.g. Osumanu 2008; Zhong and others 2008). The few peerreviewed, quantitative comparisons of private and public water utilities that exist focus mainly on production efficiency and water pricing (see Davis 2005). Studies that have analyzed differences in customer attitudes and perceptions focus mainly on satisfaction with services (e.g. Ogden 1997; Hall and Lobina 2004). In this article we explore whether water conservation behaviors may be affected by whether the water service provider is public or private and whether, in turn, this makes a difference to utilities' approach to conservation.

California is a good case for such research given the mix of public and private arrangements in the State, literally one next to the other. Several excellent studies discuss the efficacy of demand-side management policies in times of shortage in California (e.g. Berk and others 1993; Pint 1999; Renwick and Archibald 1998; Renwick and Green 2000), but these do not explore the distinctions between public and private utilities. Through customer surveys we ask whether there are any differences in the willingness to accept more stringent conservation or higher water prices between adjacent publicly controlled and privately controlled utilities. Conversely, through interviews and surveys of utility managers, we ask if there are differences between the conservation strategies of California's public and private utilities during periods of water shortage. Based on our findings, we develop hypotheses to explain the differences, if any.

Our research finds that, in California, recent and controversial privatizations do exhaust the willingness of users to cooperate with the utility. Users are especially resistant to mandatory restrictions and to price hikes. Users in older, more established privatizations do not differ significantly from users in public water systems, although there appears to be a minority with strong opinions against private control of water. Almost all users expressed their willingness to conserve voluntarily in a drought. In California the wholesale supply remains in public hands (e.g. the State Water Project) and the state remains active and visible in drought planning and management. We hypothesize that these features, together with the pro-conservation values revealed by our surveys, reinforce the collective rather than commodified nature of even "privatized" water. Our results pertain to California and cannot be assumed to hold elsewhere; however, our effort to understand willingness to conserve or pay as a function of who is being paid suggests that specific histories of drought and of privatization play a significant role in consumer perceptions.

We find that the role of state agencies remains central to the functioning of privatized utilities. Private utilities in California tend to wait for the state to declare a drought before they put pressure on their customers to conserve and they prefer to run conservation programs with, or through, their overseeing public water agencies. This way, in times of water stress, it is more the state making demands on its citizens than a corporate entity making demands on its customers. Our surveys show that, in responding to droughts, California's public (i.e. municipal) systems are more flexible and proactive than their regulated private counterparts.

\section{Methods}

To investigate consumer attitudes toward private and public utilities, we conducted a random telephone survey of 600 water users in three pairs of urban water service areas in California. Randomization was intended to eliminate researcher bias and to get a representative sample; the latter, of course, cannot be guaranteed. Our sampling frame was the customer list of each of the six utilities. These were San Jose versus San Francisco (serving over 750,000 


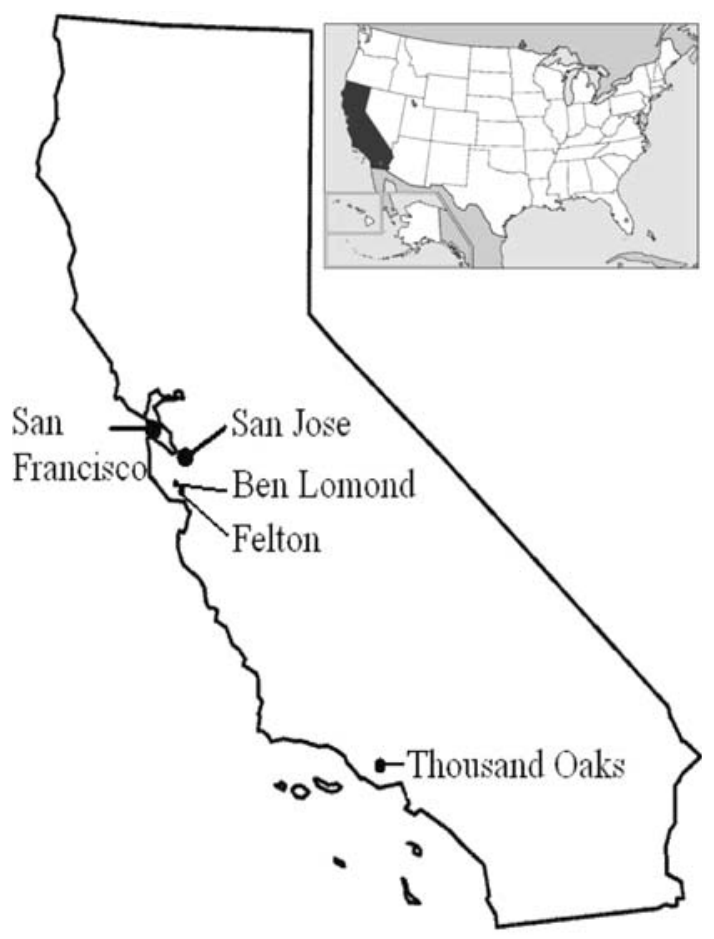

Fig. 1 California and the six case studies

customers each), Thousand Oaks (in two parts, with over 40,000 customers each) and Felton versus Ben Lomond (serving between 1000 and 2000 customers each) (Fig. 1 and Table 1). In each pair, one urban water system is owned by a public utility and the other is owned by a private utility. In each private case, the assets had been divested, permanently or at least for the long-term, to an investor-owned corporate entity. We selected adjacent areas to minimize the effects of cultural, urban form and socio-economic differences, but within-pair differences remain (see Table 1). Media coverage of water privatization also differs across these communities. There has been significant regional and state coverage of the privatization and the subsequent price hike in Felton. In Thousand Oaks and San Jose there has been little to no coverage given that both are established privatizations. In San Francisco there is limited coverage of water utilities, but more press on a highly visible controversy over many years concerning proposals to municipalize the private electricity company (PG\&E).

The survey assessed (i) how willing users were in each service area to respond to voluntary appeals for (a set of hypothetical and increasingly demanding) cutbacks during periods of water shortage; (ii) how users might respond if their provider required them to cut back on water use; (iii) how willing users were to pay higher water prices to cover the cost of infrastructure improvements; (iv) if users thought that their responses would be influenced by whether their providers were public or private; and (v) whether users were aware of the public/private character of their utility. The survey also gathered data on the degree to which users were already practicing some forms of water conservation, their average monthly water bills, and their annual household incomes.

In designing the survey, we kept in mind the wellknown shortcomings of randomly sampled telephone numbers as a proxy for the broader population of interest. These shortcomings include not speaking with an appropriate respondent, possible sample bias because of who is likely to be home to take the call, respondent dropout before the survey is completed, possible biases because many refuse to participate in any phone survey, and possible selection bias because of respondent interest in the topic of the survey (see Bryman 2008). We took several measures to avoid such biases in our sample. These measures included speaking only with adults, noting if the household was responsible for paying its own water bills (as many renters in California do not pay their own water bills), making calls at different times and days during the week, keeping the survey as short as possible and revealing our specific survey topic only after the respondent consented to being interviewed. We introduced the question about the private or public character of the water utility only as the survey was coming to a close.

We recognize that how users respond to questions regarding hypothetical situations is not necessarily predictive of actual actions once users are placed in those situations. The social psychology literature on environmental values and habits has repeatedly shown poor correlation between stated pro-conservation values and actual user behavior (e.g. Hamilton 1985; Aitken and others 1994; de Oliver 1999). Other research argues that some specific attitudes, e.g. the perceived value that a garden adds to the home, are better predictors than others of consumers' water use (Syme and others 1991). This literature is mixed on the ability of conservation messages or education to reduce water use; it has been shown to have some (albeit limited) effect (Thompson and Stoutemyer 1991; Howarth and Butler 2004), especially when consumers were made aware of the dissonance between their stated values and their actual habits (Dickerson and others 1992; Aitken and others 1994). As with the demand-side management literature cited above, few of these explicitly consider the effect of privatization on consumer attitudes or behavior. In this article, we present user responses not as predictions of future water use, but as current perceptions that may reveal which policy changes are likely to be more or less acceptable.

To investigate how water utilities view their users, and what they expect they can or cannot ask of them in periods of drought, we conducted a telephone survey of conservation managers in 31 (randomly selected) private and 34 public utilities through the summer and fall of 2007. Although decisions in utilities are made by broader teams of managers, 


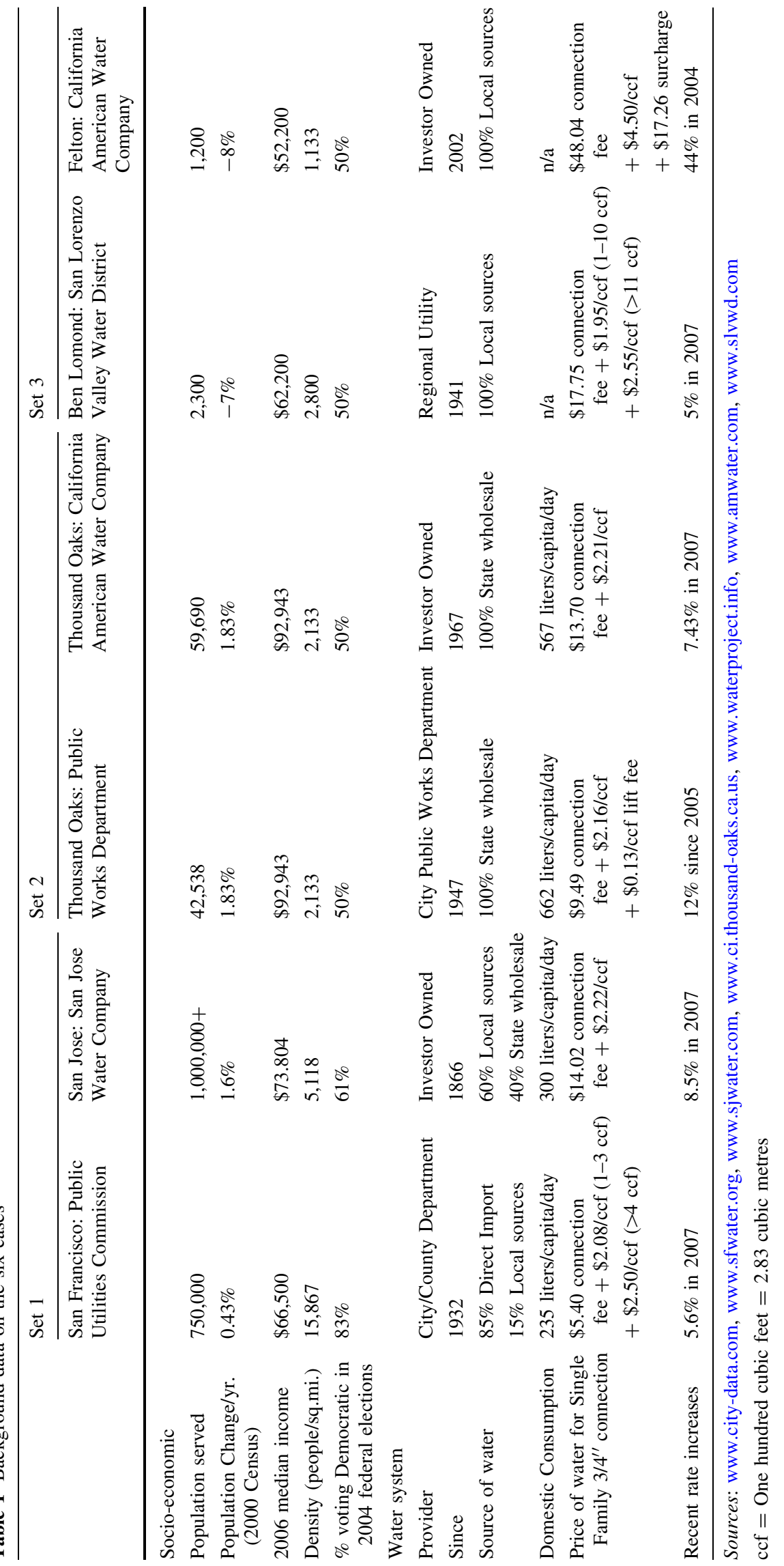


conservation managers are those on the frontline. 2007 was a dry year statewide. By July, 17 California counties were declared to be drought disasters, and the rest of the state was in "moderate to severe" condition. Because droughts occur slowly, over a multi-year period, water managers are under pressure at the first signs of drought, lest the following year also be a dry one. And indeed, 2008 in California was also dry. By May 31, 2007, reservoirs in Northern California were at $91 \%-97 \%$ of their historical capacity for the time of year; by May 312008 these figures had fallen to 58-94\% (http://watersupplyconditions.water.ca.gov).

The telephone survey of conservation managers asked whether their utilities issued calls for water conservation in the summer of 2007 , if any mandatory cuts on water use were issued, and what types of messages and tools were used to inform the users about drought conditions and the actions they should undertake to conserve. The survey also collected information on the source of the water for each utility. Utilities that relied, for example, on local surface sources in drought-affected areas had the greatest incentive to act early to counter the drought. Utilities relying on groundwater are more buffered. The State Water Project, from which many utilities import water, was not officially in a state of drought, but some utilities were already reacting to the lower than average runoff from the Sierra Nevada watersheds, and to court orders to restrict the Project's withdrawals from the California Delta to protect the endangered Delta Smelt. In addition to these surveys, for all 65 utilities, we analyzed the content of information sheets containing conservation calls that were sent to their customers and (often) posted on their websites.

Finally, we conducted in-depth interviews with key informants: water conservation managers in one public and one neighboring private utility. Both are in the same catchment and dependent on local sources, and both faced drought conditions over the summer of 2007. We discussed whether and how they tried to make users consume less water, the messages they used to induce conservation, and more generally their views of how their customers perceived them. Our primary goal for these interviews was to understand better the reasoning behind the messages and approaches chosen for their respective conservation calls, and the extent of conservation hoped for or expected from their respective customers.

\section{Results of Users' Survey}

This section presents the main results of the users' survey. We provide evidence concerning users' awareness of the public or private character of their utilities, and their willingness to conserve water, accept mandatory conservation and pay higher rates. We report data aggregated over the three public versus the three private utilities, and also the results for each public-private pair. For all questions with yes-no-n/a responses, we conducted t-tests to determine if the reported difference in proportions within each utility was significant. For questions that had a range of responses, such as a three-part positive-negative-neutral, or a five-part willing to unwilling, we conducted chi-squared tests to see if the overall responses were significantly different in the private versus public parts of each paired set. Throughout the text, we report those results for which the proportions t-test or chisquared test was significant at the 0.95 level.

\section{Awareness of Public or Private Character of Provider}

Aggregate data for the public versus the private utilities show that users overall have comparable levels of awareness of who their provider is and whether it is public or private. In the public utilities, $63 \%$ of the respondents both knew who their water provider was and knew that it was public. In the private utilities $73 \%$ knew the provider and $62 \%$ identified it as private. Disaggregated data, however, reveals Felton as the case with near-universal awareness (at $91 \%$ ) of the provider and private ownership. Felton and Ben Lomond are the only utilities in which the awareness levels were statistically significant.

Privatization in Felton is recent and controversial (Squires 2008); many of our interviewees talked spontaneously about privatization and had strong opinions about it. (We note that in June 2008, after we had completed our data collection, the water system in Felton was bought back by a local entity; see www.remunicipalisation.org). Responses such as "they're a sham" (interviewee \#531) came up at the mere mention of "water provider." A spillover effect of Felton's privatization controversy to neighboring Ben Lomond may explain its high levels of awareness about the municipal character of the provider. Twenty interviewees from Ben Lomond brought up privatization in Felton, again without prompting. Most used phrases such as "it's a disaster in Felton" (\#491); "our neighbors are getting gouged by a private company" (\#423); or "I hope our water doesn't get bought by a foreign company" (\#449). In comparison, in the older, well-established privatizations of Thousand Oaks and San Jose, there were few spontaneous references to the private character of the provider. In fact in San Jose and Thousand Oaks-CalAm more users knew who their provider was than knew that it was private.

\section{Responsiveness to Conservation Appeals}

The stated willingness of users to respond to appeals to conserve water voluntarily is generally high, except for the rather drastic step of "stop watering the garden". As expected, more users are willing to make modest rather 
Fig. 2 Stated willingness to conserve water voluntarily. Aggregate results
Your water utility claims to be facing a water shortage, so they are asking their customers to help by cutting back on water in the following ways, would you be willing to...

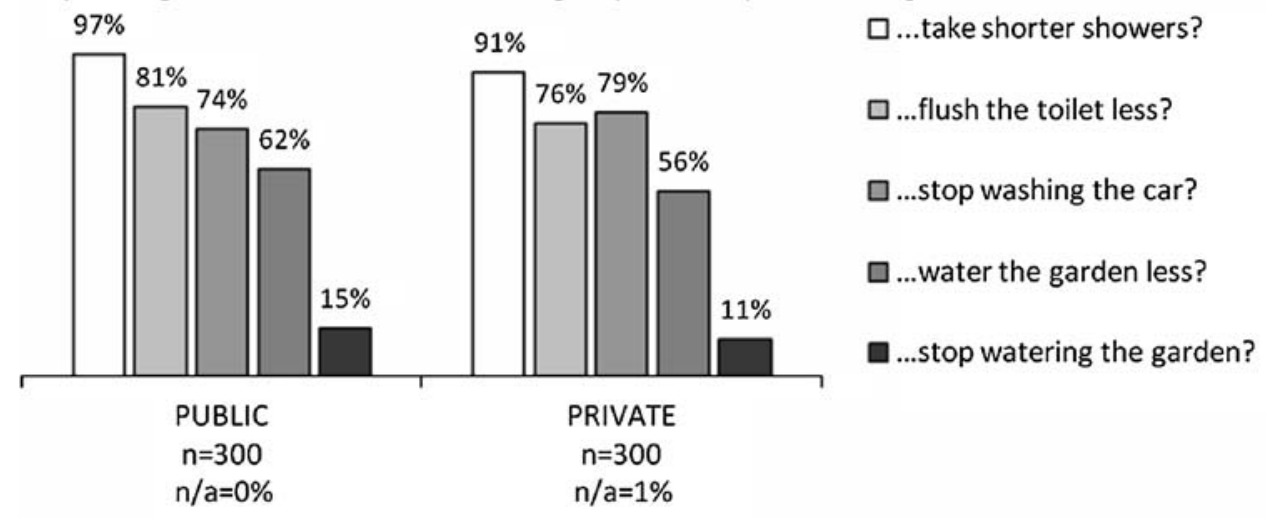

than severe cutbacks (Fig. 2). There are no statistically significant differences between users in public and private utilities overall. The pairwise comparisons show a similar pattern of across-the-board responsiveness. The similarity between statements in public and private utilities indicates a baseline profile of conservation willingness in these municipalities.

The comments that many interviewees spontaneously added to our discussions were consistent with the proconservation sentiments expressed in their survey responses. Users expressed relatively idealistic attitudes toward voluntary conservation (see also Hamilton 1983; 1985). One in ten interviewees brought up the hydrological features of California or their memories of drought in the early $1990 \mathrm{~s}$. They explicitly referred to their responsibility as good Californians to conserve water when needed. In Thousand Oaks many users were familiar with conservation calls, saying "we've done this before, we'll do it again" (\#333) or "we know what to do in times of shortage" (\#343). In Felton, several respondents who later in the interview made critical and unprovoked references to privatization were eager to say that drought is a collective problem for all Californians. One response from Felton, echoed by many, was, "in the case of drought the whole State will have to conserve" (\#508). Another respondent referred to himself as part of California's "conservation generation" (\#510). We return to this collective sense of responsibility later in the article.

\section{Willingness to Accept Mandatory Conservation}

Responses changed considerably when the question concerning conservation took a mandatory tone. Users had a less positive view of mandatory restrictions on car washing and garden watering (50\% positive in the public utilities and $36 \%$ in the private) than to voluntary appeals for the same cutbacks. Disaggregating the data into pairwise comparisons shows that Felton and Ben Lomond account for a large part of the aggregate public-private difference. The differences in attitudes to mandatory restrictions, with users in the private utilities being overall less accepting of these, are statistically significant for both Ben Lomond vs. Felton and San Jose vs. San Francisco. Differences in Thousand Oaks are within the limits of statistical error.

Users who responded positively to even mandatory cutbacks often referred to the collective character of droughts, their civic responsibilities, and their duty "to help the environment" (\#24). One Ben Lomond respondent put it succinctly: "I would comply. I'm a citizen" (\# 429). However, several respondents in public and private utilities alike said that they did not like mandatory orders and the water agencies "controlling [their] lifestyle" (\# 229).

No respondent made a spontaneous comment on the public or private character of the provider for this question, except in Felton. Answers there were characteristically negative, with many saying they would be "annoyed" (\#506) or "angry" (\#540) if restrictions were applied. Twelve respondents referred explicitly to the private character of the company with phrases such as "they are gouging us" (\#511) or "I don't trust them" (\#581). Other Felton respondents saw conservation as part of their civic duty, sometimes switching in the course of the short interview between seeing themselves as citizens of the state and as customers of the company. So while some said "as a Californian I have to conserve water if my State faces a crisis" (\#545), others, or even the same respondents, might say something like "no, they [the company] are taking advantage of the situation" (\#526).

\section{Willingness to Pay Higher Water Prices}

Other than appeals for voluntary conservation or mandatory restrictions, pricing instruments are the main response to water shortages. Willingness to pay higher rates appears 
relatively low compared to that for other responses. There were no discernible effects of household income within each utility for this response. In some instances we saw the expected positive correlation between household income and the stated willingness to pay more; in other instances there was no clear pattern. But more users in public utilities say they are willing or somewhat willing to pay higher rates $(25 \%$ versus $13 \%)$, and more users in private than in public utilities say they are reluctant or unwilling to do so (56\% versus $33 \%$ ). Disaggregating the data shows that much of this aggregate difference is due to Felton versus Ben Lomond. In all paired comparisons the unwillingness/ reluctance to pay more is higher in the private counterpart (Fig. 3), but the only statistically significant difference is between Felton and Ben Lomond. We note, however, that the median monthly water bill reported in Felton was $\$ 65$, as compared to $\$ 35$ in Ben Lomond, a difference resulting from the substantial increase of prices post privatization (Table 1). In this regard Felton is similar to other recent privatizations that have often been accompanied by higher water prices.
Public Versus Private: Do the Users Care?

For the great majority of users the willingness to conserve water does not depend on whether their provider is public or private. $80 \%$ of the respondents in public utilities and $75 \%$ in private utilities said that their responses would be unchanged based on the public or private nature of their providers. Nevertheless, a considerable minority in private Felton $(26 \%)$ said they would be more willing to conserve if their utility were public, and smaller minorities in public Ben Lomond and San Francisco said they would be less willing to conserve under a private provider (Fig. 4).

When it comes to paying more for water, the issue of utility ownership seems more salient. $58 \%$ of public and $56 \%$ of private users overall were neutral with respect to the ownership of the utility. But $56 \%$ of respondents in Ben Lomond would be less inclined to pay higher rates to a private provider; the relationship in Felton is the mirror opposite, with $64 \%$ being more willing to pay a public provider (Fig. 5). In both cities respondents repeatedly referred to "profiteering"(\#412, \#429, \#486, \#533, \#545,
Fig. 3 Stated willingness to pay higher rates. Results for each utility. Note: The $30 \%$ figure is arbitrary; we chose it because it is typical of the price increases that many private operators in California ask for in their regulatory reviews. Tenants who do not pay their own water bills were classified in the $\mathrm{n} / \mathrm{a}$ category and not included in the chi-squared tests
Your water utility claims to be facing increasing costs for infrastructure improvement. They plan to ask their customers to help cover these costs by paying higher rates of $30 \%$. How willing would you be to help? $\square$ willing or somewhat willing $\square$ neutral $\quad$ reluctant or unwilling

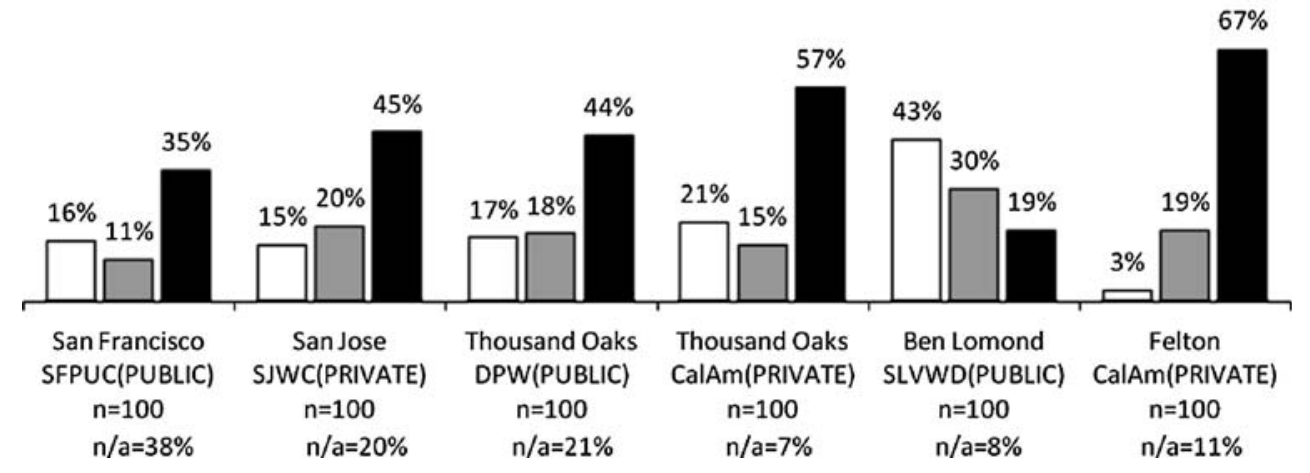

Would your willingness to conserve change based on the public or private character of your utility?

Fig. 4 Stated effect of (de)privatization on conservation responses. Results for each utility

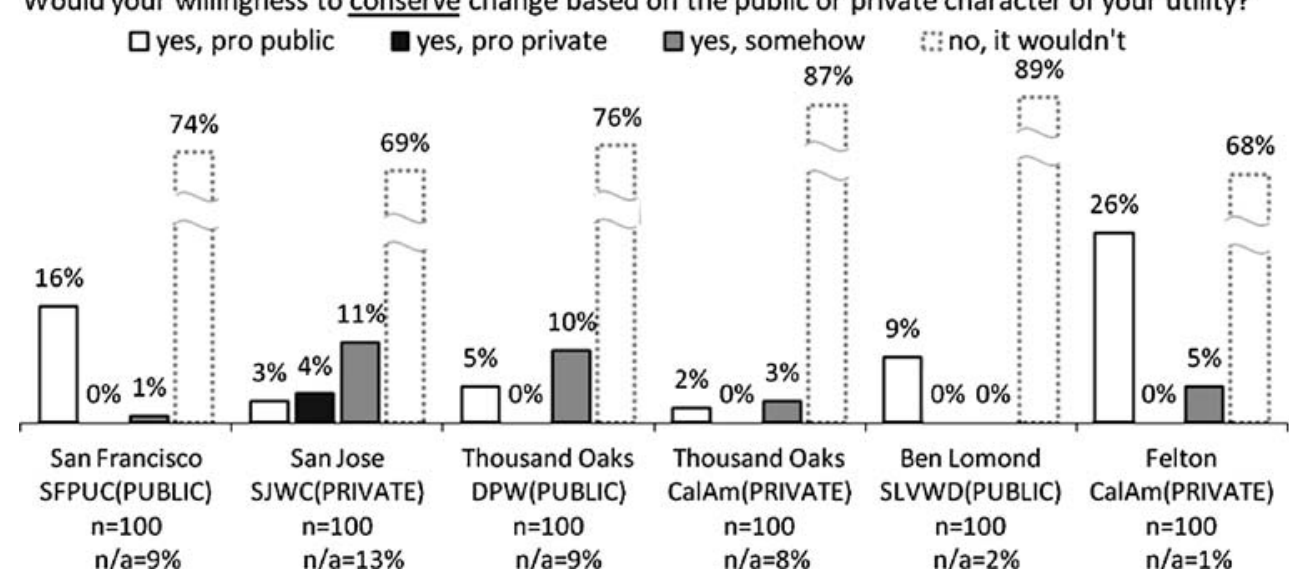


Fig. 5 Stated effect of (de)privatization on pricing responses. Results for each utility

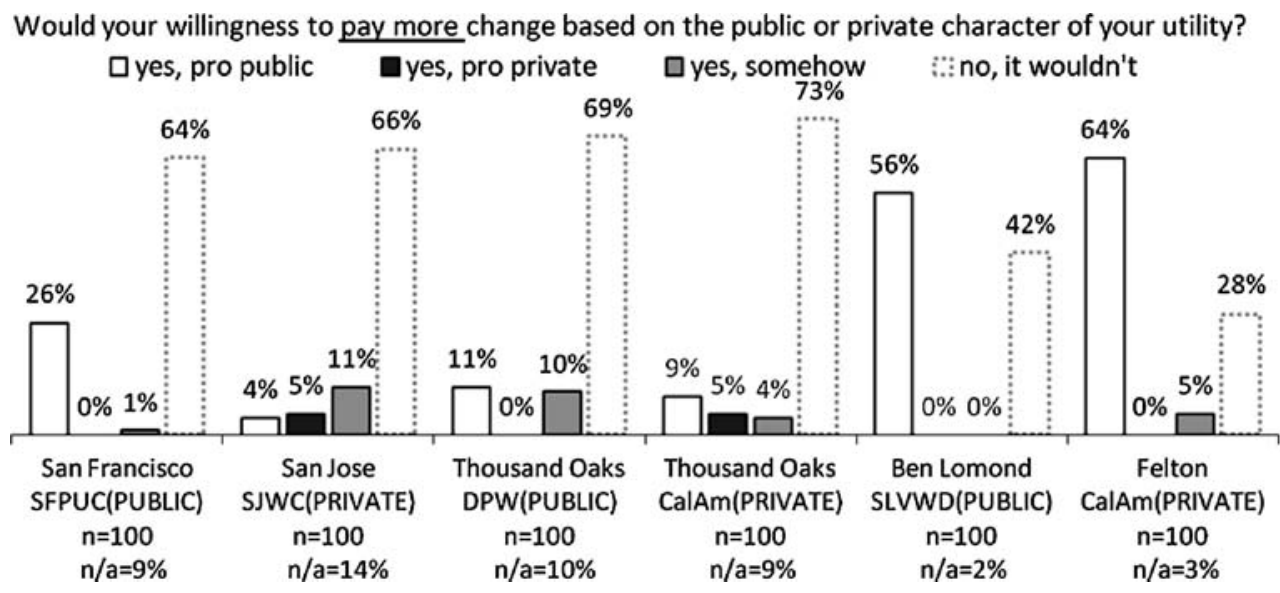

\#572). Pairwise differences between Felton and Ben Lomond and between San Francisco and San Jose are significant at the 0.95 level.

Overall, for most users outside of Felton and Ben Lomond, the private control of water provision does not affect willingness to conserve water voluntarily or to pay higher rates. However, a minority of users in each paired set voiced a greater willingness to cooperate with public rather than private entities. Not a single respondent from any public utility said that they would be more willing to conserve or pay more if their provider were private.

We invited respondents to explain their answers with respect to their attitudes toward utilities being public or private. Concerning voluntary conservation, many to whom privatization did not matter emphasized that water conservation is not about private or public: "Water is water" (\#109, \#274, \#380). Others referred to the "universal value of conservation" (\#487). In Felton, some users explicitly separated conservation from the complaints they had about the company; as one put it, "we need to conserve in California" (\#527). In response to our pricing questions, however, negative references to the character of the utility were made in all three private cases. Users linked their unwillingness to pay to utility profits, managers' high salaries and monopolistic supply conditions. In San Jose responses included "they have tons of money" (\#193) or "they are charging [for] perks for the Board, they could allocate resources better" (\#194). In Felton almost all comments were explicitly linked to the water company: "they make enough money" (\#542); "they don't deserve anything more" (\#591); and "I hate them" (\#507). In addition some users expressed lack of trust in a private provider ("I wouldn't believe them" (\#258, \#408); or "I wouldn't trust them" (\#417, \#535). Similarly negative comments came up in Felton and Ben Lomond also in response to the question about mandatory conservation.

We now disaggregate the results of willingness to pay more or to conserve more by those who knew and those who did not know the public or private nature of their provider. In our interviews, about two thirds of respondents in public and private utilities knew the nature of their provider. The overall patterns and differences described above remain after this disaggregation. For example, there is no difference in attitudes toward voluntary cutbacks between those who knew and those who didn't know in public and private utilities. But within private utilities we see that those who knew that their provider was private appeared even less willing to accept mandatory restrictions or to pay higher rates than those who did not know it (Fig. 6). When broken down by utility, the differences are pronounced within Felton and Thousand Oaks private, but less so in San Jose. The public utilities showed no similar differences.

\section{Summary of User Surveys}

Where privatization has been recent and controversial, as in Felton, users in the community as well as adjacent ones are very aware of who their provider is and its private or public character. Where privatization is old and well established, as in San Jose or Thousand Oaks, users are less likely to know that their provider is private. Users in all utilities show high and comparable levels of willingness to respond to voluntary appeals to conserve. Mandatory cutbacks are less acceptable than voluntary appeals. Users in private utilities appear more resistant to mandatory cutbacks, especially when they know that the utility is private. Users across the board are negative toward price hikes, even more than toward water use restrictions. There is a baseline pro-conservation sentiment among Californians, partially linked to the collective attributes of the water system. These include state ownership and operation of wholesale water supplies, statewide vulnerability to the same weather conditions, collective experience of recent droughts, and the widely appreciated environmental benefits of conservation. Most users believe that their willingness to pay and especially their conservation behaviors do 
Fig. 6 Aggregate results for mandatory conservation and higher rates from users who knew and didn't know if the utility was public or private
Given mandatory rationing orders, the percent and number of respondents who reacted...

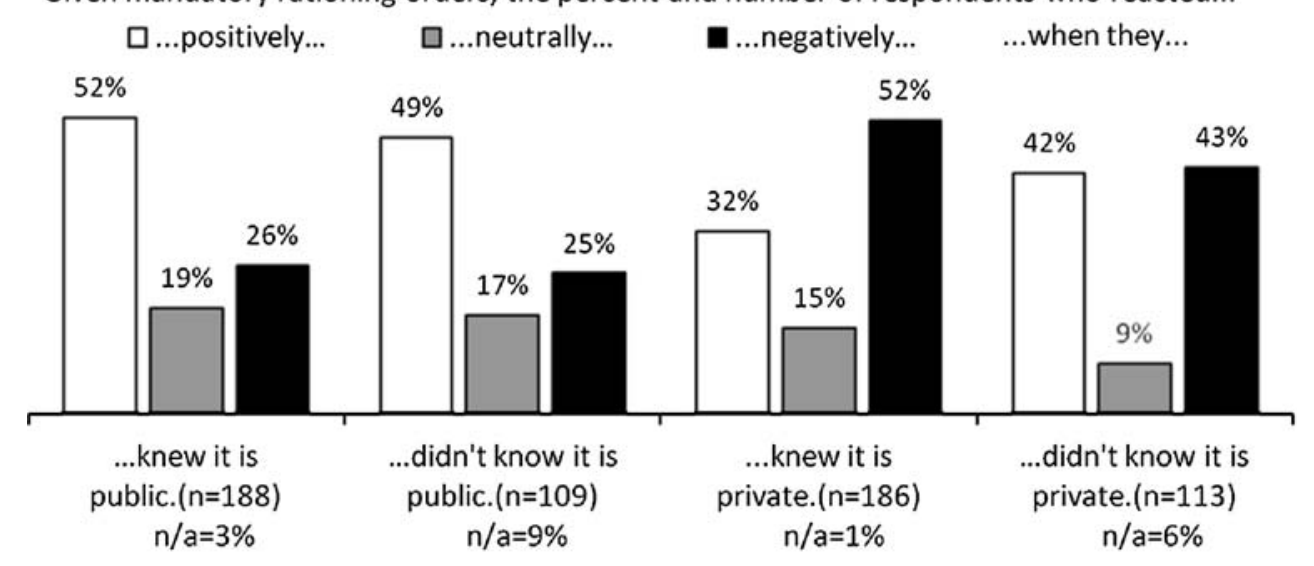

Given a $30 \%$ rate increase, the percent and number of respondents who were...

$\square$ willing or somewhat willing $\square$ neutral $\quad$ reluctant or unwilling ...to comply when they...

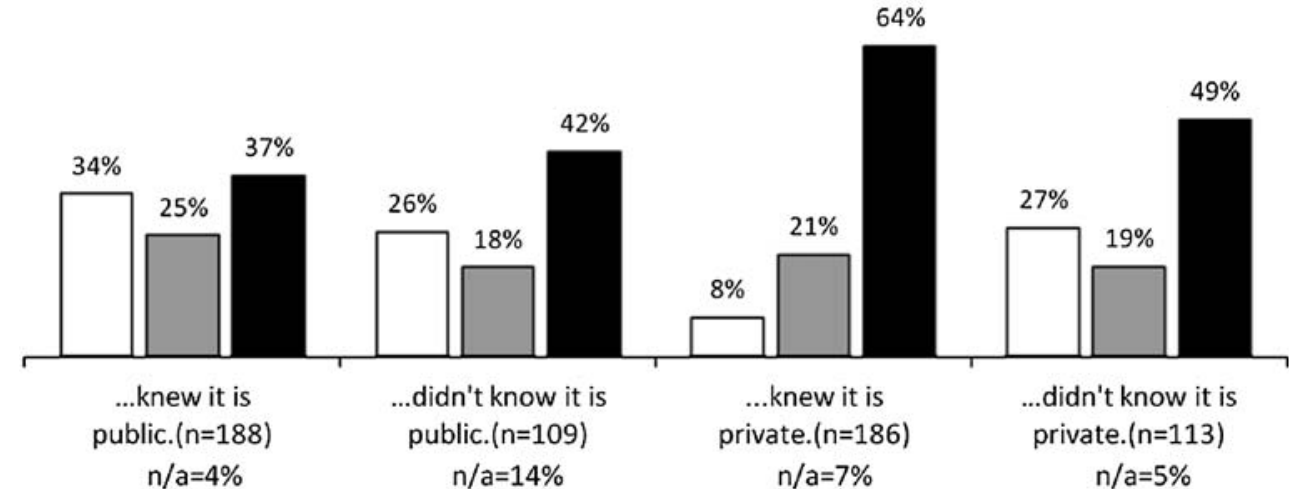

not depend on whether their provider is public or private. A majority of users in Felton, however, as well as in adjacent Ben Lomond, say they would be more willing to pay higher rates or to conserve if the provider were public. There are indications of latent anti-privatization views in other utilities too, as sizeable minorities (10-20\%) would be more willing to conserve or pay more if the provider were public. Private profits, lack of trust, and high prices were some of the reasons given by respondents who were more willing to conserve or pay under a public provider. No user served by a public utility expressed greater willingness to conserve or pay more with a private utility.

\section{Results of Utilities' Survey}

We now discuss the results of our surveys and interviews with managers in private and public utilities, and our content analysis of their conservation calls to their customers.

Providers' Responses to Drought of 2007

Our comparative analysis of 34 public and 31 private providers during March-November 2007 shows that, while most did not initiate conservation measures, public providers were somewhat more likely to act proactively and appeal to their users to use less water because of the drought. Out of the 65 utilities in our sample, 16 said they had called for additional conservation that summer, and 13 of those were public. The difference remains even after taking into account the use of groundwater, a source that could partially buffer the utility from drought. Among agencies where surface water is the main source (groundwater $<50 \%$ of supply), more public than private utilities called for voluntary rationing. Two public utilities that relied mostly on groundwater issued a conservation call. Private providers in California tend to be smaller than public providers, but size should not affect the ability to implement the soft conservation measures typically used in early stages of drought. Proactive measures in these early stages consisted primarily of appeals to cut back on specific water uses such as landscape watering, stepped up outreach and monitoring, and incentives to use water-conserving appliances such as low-flow showerheads.

Private utilities in California are under the jurisdiction of, and in some cases are supplied with water from, larger, public districts. These have the responsibility for monitoring drought conditions, for declaring severity stages, and 
activating predefined responses. Private utilities cannot mandate water restrictions on their own authority, but they can ask the regulator to allow them to do so, and they do not need permission to ask for voluntary rationing. Private utilities are free to take the initiative and appeal for voluntary rationing, simply by notifying the regulator, the Public Utility Commission (PUC). For mandatory rationing, prior approval from the PUC is required. The costs of the rationing program can be recovered if future price reviews approve the cost.

In California, therefore, water conservation is not the business only of providers at the municipal level, but also of state water agencies, wholesale providers and regional water districts. Regional initiatives in the summer of 2007 included the "Water Saving Hero" campaign by Bay Area water organizations, the $10 \%$ conservation campaign of the Santa Clara Valley Water District and the 20-gallon per person challenge of the San Diego Water Authority. Eight providers (6 public and 2 private) ran their water conservation campaigns through one of these initiatives. The public providers that adopted these initiatives ran them as (or with) their own campaigns by providing information on their websites, local newspapers, etc. In contrast, the two private providers directed us for further information to their (public) wholesalers/districts. Another private company manager in our sample reported that they did not have a conservation campaign because they "didn't want to duplicate" the wholesaler's campaign (\# Utility Interview (UI) 40).

As an example of how the utilities in our sample motivated their conservation calls, we contrast the approaches of public Santa Cruz and private California America (CalAm)-Monterey. The two cities are located at opposite ends of the Monterey Bay and face the same hydro-climatic conditions. The responses of these utilities to the drought conditions of 2007 reflect the differences we found in the larger survey. Santa Cruz acted earlier and more aggressively. Specific conservation targets were set, voluntary rationing was requested, outdoor irrigation was restricted, and standing ordinances that prohibit water wastage were reinforced through additional reminders and publicity (Fig. 7). Monterey-CalAm acted later, did not call for voluntary rationing of specific uses and did not prohibit specific actions. Instead of a targeted constraint message, it called for a general caution on water consumption, appealing to the environmental value of a healthy and
Fig. 7 Santa Cruz's conservation call; May 2007 (Rescinded April 2008). Note: Managers at Santa Cruz Water monitor the condition of their resource system and can go regularly to the City Council for approval either to implement or to remove rationing. Though 2008 was also a dry year, the utility decided to rescind the landscape irrigation prohibition in April because, "the bottom line is, we did not see the same level of drawdown of our reservoir as we projected for 2007" (Toby Goddard, Water Conservation Manager, Santa Cruz Water District, personal communication)

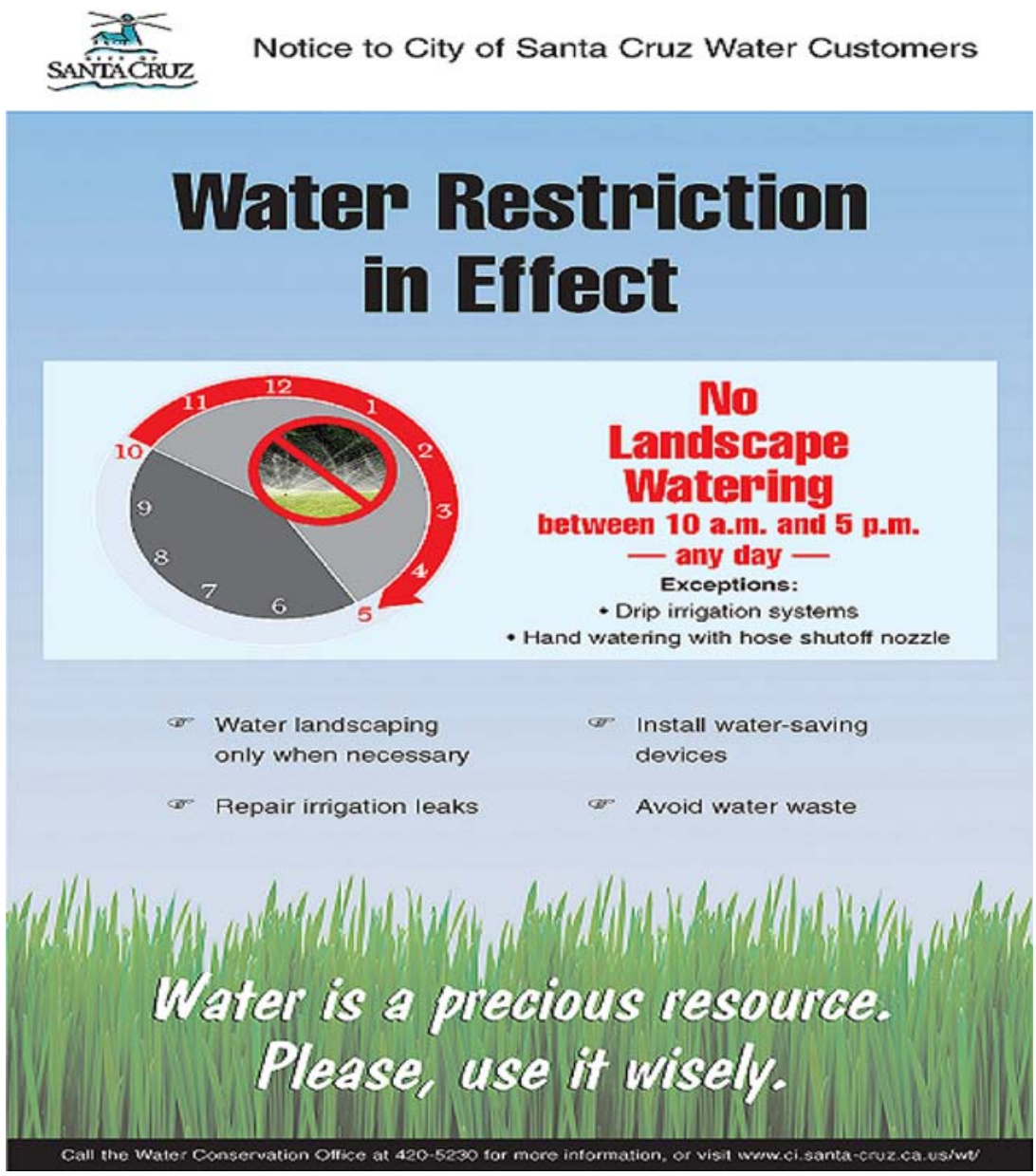


Fig. 8 CalAm Monterey's conservation call, 2007

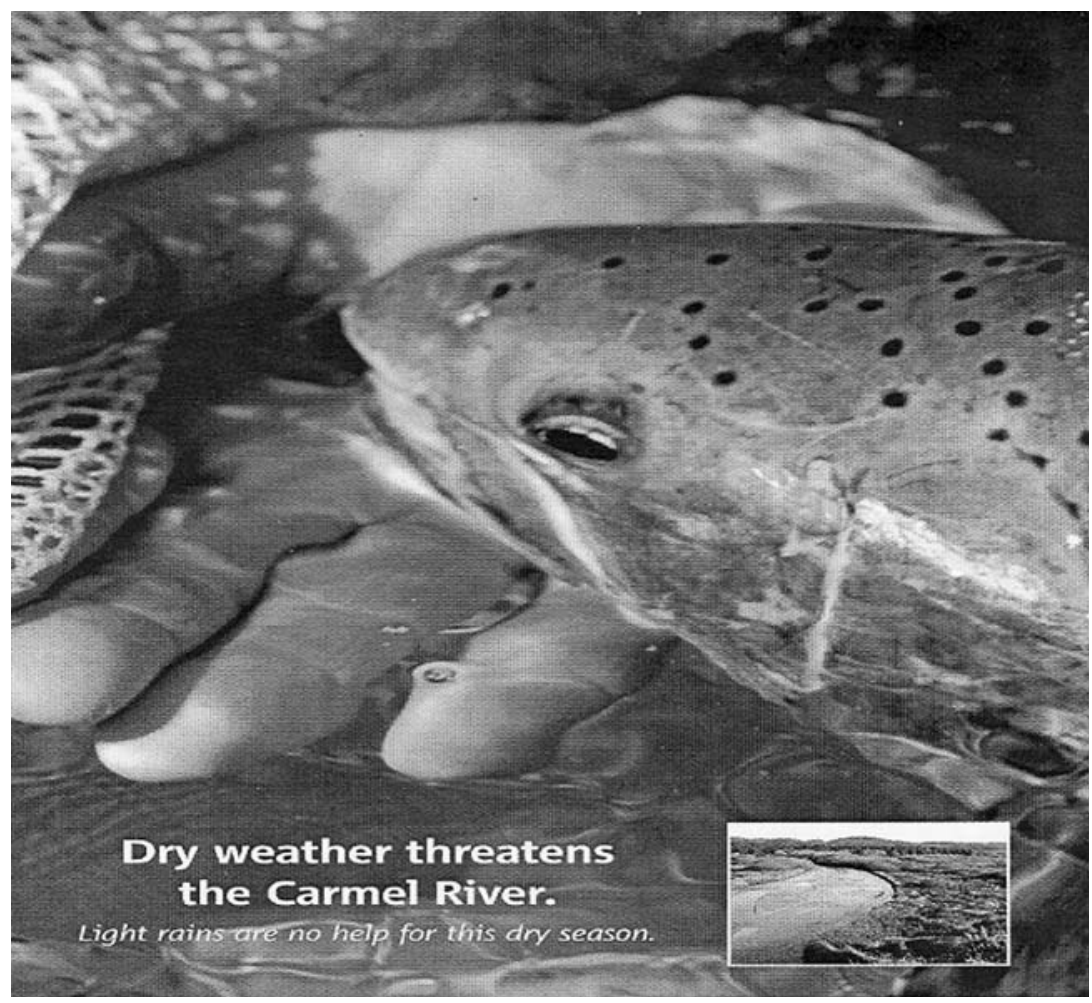

replenished Carmel river (Fig. 8). The Monterey Regional District had declared a Level 1 drought severity by Fall 2007, but CalAm kept a low profile, and, rather than publicize the attendant restrictions on its website, directed its users to the District's page.

Our initial research question was whether private and public utilities differ in their conservation approaches and, if so, whether this is partly a response to different expectations of their customers. In this respect, the words of a private company manager, responsible for two of the cities in our sample, seem relevant. Justifying why her company did not take action during the summer's drought, she told us: "we are a private company so it is very difficult to tell customers to do things" (\#UI42). Another private manager cited public indifference to such appeals: "in the past we asked customers to voluntarily conserve, and they didn't conserve at all" (\#UI56). A different explanation given by a respondent from a company responsible for three cities was that it is not within his company's authority to decide when to restrict water usage; this is the task of the public authorities that oversee it (\#UI56). Our utilities survey suggests that there are some public-private differences in California and that these are in part driven by the utilities' perceptions of their customers, but with our small number of responses this must be more a hypothesis than a conclusion.

Differences in the financial incentives of public and private utilities might also play a role. In principle profit (rather than price) regulation of private companies by PUC intends to remove disincentives for water saving. Private utilities can recover conservation expenditures if the PUC has approved a related program and/or a statewide drought emergency has been officially declared. Such "revenue adjustment mechanisms" to recoup losses are created on a case by case basis, and not all private water utilities have made yet the shift. Profit regulation on the basis of returns to capital is also more likely to reward systems expansion and less likely to reward those conservation measures that cannot readily be capitalized.

To further explore what might underlie our survey findings, we decided to conduct extended interviews with the water managers of two utilities who agreed to speak with us. One is public and the other private; they are located close to one another and were subject to the same drought conditions in 2007. We asked our interviewees to reflect both on their own utilities' conservation strategies and on the differences we found between public and private utilities in our sample. We now turn to the insights from these interviews, not treating them as "representative" of public versus private utilities, but as illustrative of insider accounts of utility management in California.

\section{Utility A and Utility B}

We refer to the two utilities whose managers we interviewed as Utility A and Utility $B$ to protect the 
confidentiality of our interviewees. Both utilities rely on local water sources, A on surface water and B on groundwater. Utility A is a public entity and Utility $\mathrm{B}$ is a subsidiary of a private company. Utility $\mathrm{B}$ is under the jurisdiction of a Water Management District ('the District'), responsible for the regional drought plan. Prices, profits and mandatory rationing for Utility $\mathrm{B}$ are regulated by the PUC.

In our interviews, the city-run utility representatives were quick to emphasize the differences between a city water department and a private corporation. A city department (they argued) has to strike trade-offs between water services and other public goals. Private corporations have to show profits, which reduces the scope for revenuereducing conservation measures. A city department can plan for restrictions whereas a private corporation tends to plan for nearly $100 \%$ supply reliability. Utility A's managers argued, with no prompting from us, that this reflects both the different mindset of private corporations, and different expectations of users, who are less tolerant of restrictions from private companies. The accountability of municipal utilities to the public through town-hall meetings and other fora gives them the legitimacy to ask for sacrifices or mandate cutbacks if needed. Their private counterparts instead are expected to deliver service whatever the cost. This was perhaps the reason why some private utilities were keen to link conservation measures to environmental factors and their obligations to environmental regulators. In our interviewees' opinion, private utilities want to make clear that reducing consumption is good for the environment (thus appealing to their users as citizens of California as opposed as customers of their product), and that external regulations (i.e. the state) are responsible for any forced conservation.

Interviewees at Utility B agreed that many of their corporate colleagues in the rest of the U.S. see a conflict between conservation and a mandate to "sell water". They argued, however, that this is less the case for private utilities in California, because profit regulation by the PUC partially delinks consumption from revenue. Utility B's conservation call in 2007 was softer than Utility A's early, targeted and well-publicized efforts to conserve. Why did Utility B not emulate the actions of Utility A, and ask for voluntary rationing, in the same hydro-climatic conditions, especially if, according to interviewees, PUC regulation reduced profit disincentives? According to our private utility interviewees, the main driver of water management was the environmental regulator's constraints on maximum allowed withdrawals, not hydro-climatic conditions as such. In terms of allowed withdrawals, Utility B was doing well. Furthermore, Utility B could not recover expenditures from any rationing campaign unless a statewide drought had been declared and the PUC allowed it to recover costs.
Utility A was not thus constrained. In effect, there was an economic incentive to wait for harsher conditions.

Utility B managers did not agree with our Utility A interviewees that private companies were unlikely to implement mandatory rationing. They argued that if the "going gets tough", the District would declare higher drought severity stages and then they would have to implement the rationing measures foreseen in the regional drought plan. Our interviewees did confirm that conservation outreach linked to the environment provides good publicity for a private water company in California. Furthermore, California-wide feelings of the need to protect the common good make it acceptable to impose rationing during severe droughts. But the utility recognized that interventionist approaches such as rationing could be problematic for customer relations. This is precisely why they do not wish to "burden" users before a drought has been formally declared. It is the State or the District that declares drought emergencies and the PUC that approves rationing. As far as Utility $\mathrm{B}$ is concerned, it simply implements the orders of accountable, civic entities.

Our interviews suggest that one reason that fewer private than public providers asked for voluntary rationing in the early stages of the 2007 drought is that they were waiting for the drought to become more severe. Regulators could then approve and activate rationing (and allow recovery of related expenditures), and public opinion would become more tolerant of company-imposed restrictions. With respect to drought-related conservation, therefore, private utilities appear locked into working at the pace of the regulatory process. Public utilities are more flexible to act proactively and adapt to changing local conditions. The City of Santa Cruz for example, was the first utility in the State to implement voluntary rationing (April 2007; see Fig. 7) but also the first to repeal them. Between Utilities A and B, private B appeared more prepared to impose mandatory rationing - since the responsibility would be borne by the regulator. Of Utility A and B, it was Public A that had assessed in advance the impacts of curtailment on its customers, so rationing programs could be adapted to its users' needs and perceptions. For Utility B, in the words of an interviewee, "the main customer of the company is the regulator".

\section{Summary of Utility Surveys/Interviews}

Based on our surveys of 65 water utilities, and on extended interviews at a public and a private utility, we suggest that public utilities in California are more likely to act proactively and ask for voluntary rationing at the early stages of a drought. Private utilities are keener to wait for regulatory orders before calling for restrictions. They are also more likely to delegate conservation activities to, or share them 
with, public agencies. This is partly because they feel the conflict between selling water and requiring reductions in consumption, partly because of the regulatory framework and partly because their consumers may not tolerate company-imposed rationing. Where possible, the greater common good (such as healthy rivers or healthy fish) is alluded to as a justification for even soft conservation calls.

Public utilities also launch strategic appeals to the environmental values of their customers. They, too, are concerned about their customers' tolerance for cutbacks; several of our interviewees pointed out that they face irate customers regularly in open, public meetings. But they appear less reluctant to ask for specific cutbacks or to police water wastage, even in the absence of regulatory oversight. In this way, they seem more confident of their legitimacy, and are more flexible to act since they do not rely on higher order authorization.

\section{Public Versus Private: Does It Matter for Conservation?}

Our starting research question was whether individual conservation behavior is influenced by the public or private control of water provision, and reciprocally, whether there are related differences in the way public and private providers approach conservation and their users. Of our three paired comparisons, the Felton versus Ben Lomond survey provides quantitative corroboration of what has been hinted at in qualitative terms from studies elsewhere (Howarth 1999; Bakker 2000). The Felton case, suggests that privatizations and their associated reforms can reduce conservation potential by exhausting the willingness of users to cooperate. Tariff reforms by a private company attract attention to its profit making goals. If a controversial privatization effort is quickly followed by drought conditions, the newly privatized utility could find itself unable to tap user cooperation and unable to raise prices without further public resistance. Price hikes are not specific to private utilities, but privatizations are typically predicated on fullcost recovery. Higher water prices and attendant controversy have accompanied many recent privatizations (Hall and others 2005; Davis 2005), and in this sense, the Felton case is representative of many recent privatizations.

Our study is not conclusive, however, on how we should interpret the results from Felton. Do cases like Felton reveal a fundamental tension between corporate control and civic values because people do not care to make sacrifices for a private company's profits? Or are they the result of a case-specific constellation of forces (price increases, vocal opposition groups to privatization, media coverage, and subsequent drought)? These questions remain critical for understanding the public's reactions to private sector participation, not only for water that is often considered "different" (see Hanemann 2006), but for other services in which civic values are important for environmental protection.

Whether there is an intrinsic link between privatization and conservation behavior is not clear from our study. Our remaining two cases on the users' side show little a priori influence of private ownership on willingness to conserve or pay higher rates. Although our sample had a small minority with strong anti-privatization opinions, and more users seemed more willing to cooperate with a public entity, overall the majority of users surveyed did not care. Users across all utilities, including Felton and Ben Lomond, were united in their willingness to conserve voluntarily during water shortages. Most of them referred to their responsibilities as citizens and to the effects of drought on all Californians. There is a collective and vivid memory of recurrent drought in the region. Furthermore, even when part of the water cycle in California is privatized, a significant part remains under public control. The water sources are public and the major wholesale suppliers (e.g. the State Water Project) are public. The state-wide institutional framework and the widely understood environmental benefits of conservation can easily overshadow negative attitudes (if any) toward a private provider. That the forging of a collective identity regardless of utility ownership could be important in consumers' willingness to conserve during droughts has been suggested in some UKbased research (see Strang 2001; cited in Howarth and Butler 2004). Future research could extend to a different set of case studies with differences in ownership such as in England (private ownership) versus Wales (mutual ownership), though there again the presence of a strong economic regulator could temper any potential differences.

From our utilities survey it seems that California's public utilities are more likely than private companies to ask for voluntary conservation, but we cannot conclusively say why. Profit incentives may play a role, though reforms in economic regulation are diminishing some differences. Our interviews suggest that private companies are cautious about latent anti-water privatization views and that the legitimacy of private firms in the eyes of the consumer may influence the types of conservation-encouraging behaviors in which they engage. Waiting until a drought has been formally declared, prioritizing environmental values in conservation messages, sharing conservation programs with public entities and underplaying differences with public operators by stressing regulation and public ownership of water, all serve to strengthen the collective character of water, diminish the distinctiveness of private control and blur the line between state and corporation. For example, California American Water, one of the companies in our utilities sample, states on its website that, 
independent of who locally manages water, the "people of California own and control water". Underplaying its differences with public providers, CalAm states that "all operating procedures are identical ... the differences (being) in the financial model, ... (where) publicly owned water systems use ... bond measures, grants, or allocations from other funds (whereas) investor-owned water systems use money from shareholders, for which they pay a return" (www.montereywaterfacts.com; 12/3/2008). Profit here is reframed as just another financial model. Indeed, a considerable number of interviewees in our sample, and not just those in Felton and Ben Lomond, took issue precisely with private profits out of water conservation or higher prices, and linked it to their negative predisposition to cooperate.

This adaptation on the part of private utilities has a paradoxical outcome. Privatization has been promoted on the grounds that it reduces the role of an ineffective state (Lee 1999; Savedoff and Spiller 1999) or because private utilities are expected to be more flexible in dealing with change and more focused on customer needs than their public counterparts (Marvin and Guy 1997). What we find in our case is almost the opposite. First, the role of the state remains legally and discursively important after privatization. And second, the public utilities appear more flexible and proactive than their private counterparts in dealing with shortages and water conservation. The private utilities are locked into the pace of the regulatory process necessary to legitimize their actions.

Finally, our surveys and interviews show that the public-private binary, while common in the literature, and a plausible entry point for this hypothesis-generating research, should be revisited. The institutional set-up of water provision, as the case of California shows, cannot be easily classified as a public-private binary, as many functions may remain in public hands even when a significant part of the chain passes into private control. It might be necessary to unpack the differences in operation and perceptions that lie behind "private" or "public", such as revenue and its distribution, trust, distance from the users, public access to decisions, accountability to customers and the locus of control (Wolff and Hallstein 2005). In turn, this unpacking can help to envisage alternative institutional arrangements for the delivery of water services and the protection of water resources.

Acknowledgments Hanna Jacobsen conducted most of our telephone surveys with users and water managers. This project owes much to Hanna's tireless and meticulous work. Anita Milman conducted the tests for statistical significance in our comparisons of public and private utilities. This research protocol was designed in accordance with the rules of UC Berkeley's Office for the Protection of Human Subjects. We are obliged by these rules not to provide any information that would permit identification of individuals from whom we received information that is not publicly available. The managers of Utility A and B, who therefore must remain unnamed, were most generous with their time and their perspectives. We are grateful to the four reviewers of this article for their detailed comments and suggestions. Kallis' research was supported by a Marie Curie International Fellowship within the 6th European Community Framework Programme; Ray's research received support from University of California's Committee on Research (COR).

Open Access This article is distributed under the terms of the Creative Commons Attribution Noncommercial License which permits any noncommercial use, distribution, and reproduction in any medium, provided the original author(s) and source are credited.

\section{References}

Aitken CK, Mcmahon TA, Wearing AJ, Finlayson BL (1994) Residential water-use-predicting and reducing consumption. Journal of Applied Social Psychology 24(2):136-158

Bakker K (2000) Privatizing water, producing scarcity: the Yorkshire drought of 1995. Economic Geography 76:4-27

Bakker K (2005) Neoliberalizing nature? Market environmentalism in water supply in England and Wales. Annals of the Association of American Geographers 95(3):542-565

Baumann D, Boland J, Hanemann WM (1998) Urban water demand management and planning. McGraw-HilL, New York

Berk R, Schulman D, McKeever M, Freeman HE (1993) Measuring the impact of water conservation campaigns in California. Climatic Change 24:233-248

Bryman A (2008) Social research methods, 2nd edn. Oxford University Press, Oxford

Butler D, Memon FA (2006) Water demand management. IWA Publishing, London

Dalhuisen JM, Florax R, De Groot HLF, Nijkamp P (2003) Price and income elasticities of residential water demand: a meta-analysis. Land Economics 79(2):292-308

Davis J (2005) Private-sector participation in the water and sanitation sector. Annual Reviews of Environment and Resources 30:145-183

de Oliver M (1999) Attitudes and inaction-a case study of the manifest demographics of urban water conservation. Environment and Behavior. 31(3):372-394

Dickerson CAR, Aronson Thibodeau E, Miller D (1992) Using cognitive-dissonance to encourage water conservation. Journal of Applied Social Psychology 22(11):841-854

Dinar A (ed) (2000) The political economy of water pricing reform. World Bank Publications

Domene E, Saurí D (2006) Urbanisation and water consumption: influencing factors in the Metropolitan Region of Barcelona. Urban Studies 43(9):1605-1623

Hall D, Lobina E (2004) Private and public interests in water and energy. Natural Resources Forum 24:268-277

Hall D, Lobina E, de la Motte R (2005) Public resistance to privatization in water and energy. Development in Practice 15:3-4

Hamilton LC (1983) Saving water: a causal model of household conservation. Sociological Perspectives 26(4):335-374

Hamilton LC (1985) Self-reported and actual savings in a water conservation campaign. Environment and Behaviour 17(3):315-326

Hanemann WM (2006) The economic conception of water. In: Rogers P, Llamas R (eds) Water crisis: myth or reality? Taylor \& Francis

Haughton G (1998) Private profits-public drought: the creation of a crisis in water management for West Yorkshire. Transactions of the Institute of British Geographers 23:419-433

Howarth DA (1999) Privatization. A help or hindrance in managing water demand? Water Resources Update 114:18-25 
Howarth D, Butler S (2004) Communicating water conservation: How can the public be engaged? Water Science and Technology: Water Supply. 43:33-44

Ivey JL, Smithers J, de Loe R, Kreutzwiser RD (2005) Community capacity for adaptation to climate-induced water shortages: linking institutional complexity and local actors. Environmental Management 33:36-47

Jacobs M (1994) The limits to neoclassicism: toward an institutional environmental economics. In: Benton T, Redclift M (eds) Social theory and the global environment, London. Routledge, New York

Kallis G (2008) Droughts. Annual Reviews of Environment and Resources 33:3.1-3.34

Lee TR (1999) Water management in the 21st century: the allocation imperative. Edward Elgar, Cheltenham, Glos

Martínez-Espiñeira R (2002) Residential water demand in the Northwest of Spain. Environmental and Resource Economics 21(2):161-187

Marvin S, Guy S (1997) Consuming water: evolving strategies of water management in Britain. Journal of Urban Technology 4(3):21-45

Mazzanti M, Montini A (2006) The determinants of residential water demand: empirical evidence for a panel of Italian municipalities. Applied Economics Letters 13(2):107-111

Nauges C, Thomas A (2003) Long-run study of residential water consumption. Environmental \& Resource Economics 26(1):25-43

Ogden SG (1997) Accounting for organizational performance: the construction of the customer in the privatized water industry. Accounting, Organizations and Society 22(6):529-556

Osumanu IK (2008) Private sector participation in urban water and sanitation provision in Ghana: experiences from the Tamale Metropolitan Area (TMA). Environmental Management 42(1):102-110

Pint E (1999) Household responses to increased water rates during the California drought. Land Economics 75(2):246-266
Renwick ME, Archibald SO (1998) Demand side management policies for residential water use. Land Economics 74(3):343-359

Renwick ME, Green R (2000) Do residential water demand side management policies measure up? An analysis of eight California water agencies. Journal of Environmental Economics and Management 40(1):37-55

Savedoff WD, Spiller PT (1999) Spilled water: institutional commitment in the provision of water services. Inter-American Development Bank, Washington, DC

Spash CL (2008) Deliberative monetary valuation and evidence for a new theory of value. Land Economics 84(3):469-488

Squires J (2008) FLOW lawsuit stays afloat; Felton water control fight head to court this spring, Santa Cruz Sentinel. http://www. scsextra.com/story.php?sid=65025. Accessed 19 January 2008

Strang V (2001) Evaluating water. Cultural beliefs and values about water quality, use and conservation. Water UK Publications. ISBN 1840572485

Syme GJ, Seligman C, Thomas JF (1991) Predicting water-consumption from homeowners attitudes. Journal of Environmental Systems 20(2):157-168

Thompson SC, Stoutemyer K (1991) Water-use as a commons dilemma-the effects of education that focuses on long-term consequences and individual action. Environment and Behavior 23(3):314-333

Vatn A (2005) Institutions and the environment. Edward Elgar, Cheltenham

Wentz EA, Gober P (2007) Determinants of small-area water consumption for the City of Phoenix, Arizona. Water Resources Management 21(11):1849-1863

Wolff G, Hallstein E (2005) Beyond privatization: restructuring water systems to improve performance. Pacific Institute, Oakland

Zhong L, Mol A, Fu T (2008) Public-private partnerships in China's Urban Water Sector. Environmental Management 41(6):863-877 